muscle activity. All the three treatments restored the normal myoelectrical activity to a greater or lesser extent but bran was most effective. Indirect indices of colonic function were stool weight and transit time. The reduced stool weight and the prolonged intestinal transit time found in diverticular disease were both significantly changed by all three treatments, with the bran appearing most effective.

These results suggest that in diverticular disease all indices of colonic pathophysiology can be restored to normal, which supports the theory that diverticular disease results from a normal colon being subjected to abnormal dietary stress rather than from a primary or constitutional colonic abnormality. Although controversy exists on how best the bulk should be replaced, ${ }^{9}$ there seems to be no adequate replacement for substantial amounts of bran. Its unpalatability has resulted in the use of several substitutes-for example, bulk laxatives-but these do not appear to be as effective either in reducing symptoms or in restoring the normal myoelectrical activity. We have found that bran compressed in the form of tablets is not only convenient and acceptable but also effective. We have prescribed nine tablets a day (18 $\mathrm{g}$ bran) as the standard treatment but this may be varied in response to the patient's symptoms.
We thank Norgine Ltd for the kind gift of bran tablets (Fybranta Tablets).

\section{References}

${ }^{1}$ Carlson, A J, and Hoelzel, F, Gastroenterology, 1949, 12, 108.

2 Manousos, O N, Truelove, S C, and Lumsden, K, British Medical Fournal, 1967, 3, 762.

${ }^{3}$ Hughes, L E, Gut, 1969, 10, 336.

4 Burkitt, D P, British Medical fournal, 1973, 1, 274.

5 Burkitt, D P, Walker, A R P, and Painter, N S, Lancet, 1972, 2, 1408.

6 Cleave, T L, and Campbell, G D, Diabetes, Coronary Thrombosis and the Saccharin Disease. Bristol, John Wright, 1966.

7 Painter, N S, Almeida, A Z, and Colebourne, K W, British Medical fournal, 1972, 2, 137.

${ }^{8}$ Kirwan, W O, et al, British Medical fournal, 1974, 4, 187.

9 Srivastava, G, Smith, A N, and Painter, N, British fournal of Surgery, $1975,62,657$

${ }^{10}$ Hinton, J M, Lennard-Jones, J E, and Young, A C, Gut, 1969, 10, 842.

11 Taylor, I, et al, Gut, 1974, 15, 599.

12 Taylor, I, Duthie, $\mathrm{H} \mathrm{L}$, and Smallwood, R, in Proceedings of the 4th International Symposium on Gastrointestinal Motility, ed E E Daniel et al. Vancouver, Mitchell Press, 1974.

13 Awfwiddson, S, Acta Chirurgica Scandinavica, 1964, Suppl No 342.

14 Painter, N S, and Truelove, S C, Gut, 1964, 5, 201.

\title{
Once-daily dosing with atenolol in patients with mild or moderate hypertension
}

\author{
A P DOUGLAS-JONES, J M CRUICKSHANK
}

British Medical fournal, 1976, 1, 990-991

\section{Summary}

Because of the difficulties patients have in adhering to their drug regimens a trial was performed in which patients with essential hypertension were given, in random order and for four weeks each, three different doses of atenolol to be taken once daily. Atenolol effectively decreased lying and standing blood pressures, and there was no difference between the effects of the three doses. The simplicity of the regimen, as well as atenolol's freedom from troublesome side effects, should be valuable in helping patients adhere to long-term treatment.

\section{Introduction}

Atenolol (Tenormin, ICI 66082 ) is a new beta-adrenergic blocking agent which is equipotent with propranolol in suppressing exercise tachycardia. ${ }^{1}$ Animal experiments have shown that atenolol has cardioselectivity and an absence of both intrinsic sympathomimetic activity and membrane stabilising activity and that it does not cross the blood-brain barrier. It has a plasma half life in man of about eight hours. ${ }^{2}$ Initial clinical studies have indicated that atenolol, when administered two or three times daily, is effective in the treatment of hypertension. ${ }^{3-5}$

\section{Norwich}

A P DOUGLAS-JONES, MRCS, LRCP, general practitioner

Pharmaceuticals Division, Imperial Chemical Industries Ltd, Macclesfield, Cheshire

J M CRUICKSHANK, DM, MRCP, medical adviser
Patient compliance in adhering to long-term oral treatment has been much debated. It is likely to be poor if the patient is asymptomatic, as in the case of many hypertensive subjects, or if the dosage is complicated or has side effects. ${ }^{7-9}$ Although there have been relatively few troublesome side effects associated with twice-daily doses of atenolol, ${ }^{5}{ }^{6}$ the problem of patient compliance remains, and as patients probably comply best with once-daily dosages we investigated the effect of atenolol once a day in patients with mild or moderate hypertension.

\section{Patients and methods}

We studied 18 patients who all had newly diagnosed essential hypertension. The six men were aged 54 to 61 years (mean age 55 years) and the 12 women 34 to 63 (mean age 51 years). The patients were selected at the end of a four-week placebo run-in period if their diastolic blood pressure after five minutes' rest in the supine position was (a) $100-120 \mathrm{~mm} \mathrm{Hg}$ if 54 years or less or (b) $105-125 \mathrm{~mm} \mathrm{Hg}$ if 55 and 65 years. We excluded patients with a history of congestive cardiac failure (CCF), asthma, or electrocardiographic evidence of second or third degree heart block and those who were pregnant. Patients who developed CCF, asthma, symptomatic bradycardia, high blood pressure requiring urgent treatment (diastolic pressure of 130 $\mathrm{mm} \mathrm{Hg}$ or more), or side effects which proved intolerable were withdrawn from the study.

The study was double-blind, within-patient (crossover), and randomised. After a four-week placebo run-in period, the patient began active treatment provided his blood pressure conformed with the criteria set out above. The treatment comprised three randomly allocated four-week periods when either $50 \mathrm{mg}(25 \mathrm{mg} \approx 2), 100 \mathrm{mg}$ $(50 \mathrm{mg} \times 2)$, or $200 \mathrm{mg}(100 \mathrm{mg} \times 2)$ of atenolol was taken in a single dose with the evening meal. Placebo and $25-\mathrm{mg}, 50-\mathrm{mg}$, and 100-mg tablets of atenolol all looked alike.

All the patients were seen each fortnight (between 6-7 pm) and were instructed not to take the evening dose before the day of the visit to the surgery, so that a blood pressure at least 24 hours remote from the previous dose could be obtained. At each visit a resting pulse 
TABLE I-Mean blood pressure, pulse rate, and weight ( \pm SE of mean) after four weeks' placebo run-in and after four weeks of each of three treatments

\begin{tabular}{|c|c|c|c|c|c|c|c|}
\hline & $\begin{array}{l}\text { Placebo } \\
\text { run-in } \\
(A)\end{array}$ & $\begin{array}{l}\text { Atenolol } \\
50 \mathrm{mg} \\
\text { (B) }\end{array}$ & $\begin{array}{l}\mathrm{P} \text { value } \\
(\mathrm{A} v \mathrm{~B})\end{array}$ & $\begin{array}{l}\text { Atenolol } \\
100 \mathrm{mg} \\
\text { (C) }\end{array}$ & $\begin{array}{l}\text { P value } \\
(A \vee C)\end{array}$ & $\begin{array}{l}\text { Atenolol } \\
200 \mathrm{mg}\end{array}$ & $\begin{array}{l}\text { P value } \\
(A \vee v D)\end{array}$ \\
\hline $\begin{array}{l}\text { Lying blood pressure }(\mathrm{mm} \mathrm{Hg}): \\
\text { Systolic } \\
\text { Diastolic } \\
\text { Standing blood pressure }(\mathrm{mm} \mathrm{Hg}):\end{array}$ & $\begin{array}{l}168 \cdot 2 \pm 3 \cdot 35 \\
106 \cdot 5 \pm 1 \cdot 85\end{array}$ & $\begin{array}{r}142.9 \div 5.99 \\
85.9 \pm 2.84\end{array}$ & $\begin{array}{l}<0.001 \\
<0.001\end{array}$ & $\begin{array}{r}146 \cdot 7 \pm 5 \cdot 60 \\
91 \cdot 1 \pm 2 \cdot 80\end{array}$ & $\begin{array}{l}<0.001 \\
<0.001\end{array}$ & $\begin{array}{r}142 \cdot 2+7 \cdot 22 \\
88 \cdot 1 \pm 4 \cdot 33\end{array}$ & $\begin{array}{l}<0.01 \\
<0.01\end{array}$ \\
\hline $\begin{array}{l}\text { Systolic } \\
\text { Diastolic } \\
\text { Pulse rate lying (beats/min) } \\
\text { Weight (kg) }\end{array}$ & $\begin{array}{r}167 \cdot 2 \pm 3 \cdot 80 \\
108 \cdot 7 \pm 1 \cdot 80 \\
89 \cdot 2 \pm 3 \cdot 44 \\
75 \cdot 4 \pm 1 \cdot 83\end{array}$ & $\begin{array}{r}140 \cdot 2 \pm 4.51 \\
89.2 \pm 3.73 \\
65.5 \pm 1.86 \\
75 \cdot 8 \pm 1.90\end{array}$ & $\begin{array}{l}<0.001 \\
<0.001 \\
<0.001 \\
\text { NS }\end{array}$ & $\begin{array}{r}146 \cdot 5 \pm 5 \cdot 70 \\
94 \cdot 3 \pm 2 \cdot 47 \\
71 \cdot 5 \pm 2 \cdot 54 \\
75 \cdot 2 \pm 2.05\end{array}$ & $\begin{array}{l}<0.001 \\
<0.001 \\
<0.001 \\
\text { NS }\end{array}$ & $\begin{array}{r}143.9 \pm 5 \cdot 15 \\
89.7 \pm 2.47 \\
67.8 \pm 2.31 \\
75.6 \pm 1.99\end{array}$ & $\begin{array}{l}<0.001 \\
<0.001 \\
<0.001 \\
\text { NS }\end{array}$ \\
\hline
\end{tabular}

NS $=$ Not significant.

TABLE II-Response rate to three doses of atenolol. Responses are expressed in terms of falls in lying diastolic pressures

\begin{tabular}{|c|c|c|c|c|}
\hline \multirow{2}{*}{$\begin{array}{l}\text { Atenolol } \\
\text { dose }\end{array}$} & \multicolumn{3}{|c|}{ Response } & \multirow{2}{*}{$\begin{array}{l}\text { Final lying } \\
\text { diastolic of } \\
90 \mathrm{~mm} \mathrm{Hg}\end{array}$} \\
\hline & $\begin{array}{c}\text { Satisfactory } \\
\text { (fall of } 15 \\
\mathrm{~mm} \mathrm{Hg} \text { ) }\end{array}$ & $\begin{array}{c}\text { Fair } \\
\text { (fall of } 5-14 \\
\text { mm Hg) }\end{array}$ & $\begin{array}{c}\text { Poor } \\
\text { (fall of } \leqslant 4 \\
\text { mm Hg) }\end{array}$ & \\
\hline $\begin{array}{l}50 \mathrm{mg} \\
100 \mathrm{mg} \\
200 \mathrm{mg}\end{array}$ & $\begin{array}{r}11 \\
9 \\
10\end{array}$ & $\begin{array}{l}3 \\
5 \\
4\end{array}$ & $\begin{array}{l}3 \\
3 \\
3\end{array}$ & $\begin{array}{r}10 \\
9 \\
10\end{array}$ \\
\hline
\end{tabular}

TABLE III-Side effects associated with placebo and three active treatments

\begin{tabular}{|c|c|c|c|c|}
\hline Side effects & Placebo & $\begin{array}{l}\text { Atenolol } \\
(50 \mathrm{mg})\end{array}$ & $\begin{array}{l}\text { Atenolol } \\
(100 \mathrm{mg})\end{array}$ & $\begin{array}{l}\text { Atenolol } \\
(200 \mathrm{mg})\end{array}$ \\
\hline $\begin{array}{l}\text { Cold extremities } \\
\text { Tiredness } \\
\text { Wheeziness } \\
\text { Breathlessness } \\
\text { Indigestion } \\
\text { Diarrhoea } \\
\text { Constipation } \\
\text { Dreams } \\
\text { Insomnia } \\
\text { Hallucinations } \\
\text { Depression } \\
\text { Impotence } \\
\text { Dizziness } \\
\text { Rash } \\
\text { Occular symptoms } \\
\text { (blurred vision) } \\
\text { Headache } \\
\text { Cramp } \\
\text { Total }\end{array}$ & \begin{tabular}{|c}
2 \\
4 \\
3 \\
2 \\
1 \\
0 \\
3 \\
0 \\
0 \\
2 \\
0 \\
0 \\
1 \\
1 \\
0 \\
0 \\
1 \\
0 \\
20 \\
(11 patients)
\end{tabular} & $\begin{array}{c}0 \\
4 \\
0 \\
1 \\
0 \\
0 \\
0 \\
0 \\
1 \\
0 \\
0 \\
1 \\
1 \\
0 \\
0 \\
1 \\
0 \\
9 \\
\text { (7 patients) }\end{array}$ & \begin{tabular}{|c|}
1 \\
4 \\
2 \\
1 \\
1 \\
0 \\
2 \\
0 \\
3 \\
0 \\
0 \\
1 \\
1 \\
0 \\
1 \\
0 \\
1 \\
18 \\
(10 patients)
\end{tabular} & $\begin{array}{c}1 \\
4 \\
2 \\
0 \\
3 \\
0 \\
2 \\
0 \\
2 \\
0 \\
0 \\
1 \\
1 \\
0 \\
1 \\
0 \\
0 \\
17 \\
\text { (10 patients) }\end{array}$ \\
\hline
\end{tabular}

rate was recorded together with blood pressure readings (from a random-zero sphygmomanometer) after five minutes' lying and two minutes' standing. The patient was then asked about side effects (see table III).

Statistical method-Fisher's F test and Student's $t$ test were applied where appropriate and were based on blood pressure values measured at the end of each four weeks. The blood pressures obtained two weeks after starting the new treatment were not used, as carry-over effects from atenolol can last up to two weeks. ${ }^{10}$

\section{Results}

One patient was withdrawn from the trial and the statistical analysis was therefore based on the results of the 17 patients who completed the trial.

Initial blood pressure when lying and standing, lying pulse-rate, and weight and the effect of the three treatment periods on these values are shown in table I. All three active treatments decreased the lying and standing systolic and diastolic blood pressures and lying pulse rate; these changes were all statistically significant in relation to the initial placebo values. No active treatment was associated with a significant change in weight.

The order in which the three treatments were given did not influence their effect on the blood pressure. For example, the overall mean fall in lying diastolic blood pressure for all patients was $20.6 \mathrm{~mm} \mathrm{Hg}$ when atenolol $50 \mathrm{mg}$ was administered: for the six patients who received the $50 \mathrm{mg}$ as first treatment the mean fall was $21.8 \mathrm{~mm} \mathrm{Hg}$; for the five who received it second, the fall was $19.8 \mathrm{~mm} \mathrm{Hg}$; and for the six who received it last, the fall was $20.4 \mathrm{~mm} \mathrm{Hg}$. A between-treatment comparison revealed no statistical difference between the effects of the three doses of atenolol on blood pressure, pulse rate, and weight.

Patient response-Table II shows the number of patients with a satisfactory, fair, and poor response to the three doses of atenolol. A satisfactory response was defined as a final lying diastolic blood pressure of $90 \mathrm{~mm} \mathrm{Hg}$ or less : 10 patients on $50 \mathrm{mg}$, nine on $100 \mathrm{mg}$, and 10 on $200 \mathrm{mg}$ achieved this response.

Side effects-Table III shows side effects associated with the placebo and three active treatments. One patient developed asthma for the first time in her life during the placebo run-in period (thought by the investigator to be a possible allergy to fish) and she was withdrawn from the trial. Side effects were no more frequent during the three active periods than during placebo run-in period, and were somewhat fewer during the atenolol $50 \mathrm{mg}$ phase.

\section{Discussion}

Several interesting points have emerged from this investigation. Atenolol in once-daily doses seems to control blood pressure for at least 24 hours. Moreover, $50 \mathrm{mg}$ was just as effective as $200 \mathrm{mg}$. A similar flat dose-response curve has been observed by Dollery et al, ${ }^{11}$ who used thrice-daily doses from $75 \mathrm{mg}$ to $600 \mathrm{mg}$ a day. The satisfactory response associated with the low dose was not a result of controlling a blood pressure that had previously been exposed to higher doses. The fall in blood pressure was just as great when the $50 \mathrm{mg}$ dose was given first as when given last.

The fact that there was no progressive fall in lying pulse rate with increasing dosage of atenolol doses not mean that maximal beta-blockade had occurred after a 50-mg dose. A standing pulse rate value, or, preferably, an exercise tachycardia when vagal influence is minimal, is necessary to assess beta-blockade. Also, expected differences in resting pulse rate associated with different doses might, at 24 hours, be minimal or absent. ${ }^{12}$

Side effects were no more common during the active treatment phases than during the placebo run-in. This emphasises the importance of eliciting complaints from the patient before active treatment is given.

Atenolol is thus effective in once-daily doses, and the simplicity of this regimen together with its lack of side effects should make it valuable in the long-term treatment of hypertensive patients.

Requests for reprints should be addresed to Dr A P Douglas-Jones, "Melrose," 25 Mile End Road, Norwich NOR 83 E.

\section{References}

${ }^{1}$ Conway, F J, et al, British fournal of Clinical Pharmacology, in press.

${ }^{2}$ McAinsh, J, et al, to be published.

3 Amery, A, et al, Acta Clinica Belgica, 1973, 28, 359.

${ }^{4}$ Hansson, L, et al, Acta Medica Scandinavica, 1973, 194, 549.

5 Hansson, L, et al, British Medical fournal, 1975, 2, 367.

6 Petrie, J C, et al, British Medical fournal, 1975, 4, 133.

Jenkins, B W, General Practitioner, 1954, 9, 66.

${ }^{8}$ Blackwell, B, New England fournal of Medicine, 1973, 289, 249.

${ }^{9}$ Finnerty, F A, Modern Concepts of Cardiovascular Disease, 1973, 42, 37.

10 Amery, A, et al, to be published.

${ }^{11}$ Dollery, C T, et al, British fournal of Clinical Pharmacology, 1975, 2, 185.

12 Marlin, G E, British fournal of Clinical Pharmacology, 1975, 2, 151. 